\title{
A STUDY ON EMOTIONAL INTELLIGENCE OF SECONDARY SCHOOL TEACHERS OF ASSAM
}

\section{JURITIBORGOHAIN \& MITHUNMONDAL}

Research Scholar, Department of Education, Rajiv Gandhi University, Arunachal Pradesh, India

Received: May 30, 2020; Accepted: Jun 19, 2020; Published: Jun 26, 2020; Paper Id.: IJMPERDJUN2020103

\section{INTRODUCTION}

A sound programme of education in general and teacher education in particular is essential for the qualitative improvement of education. Realizing the importance of teacher education the Kothari Commission (1964-66) stated that "Investment in teacher education can yield in very rich dividends because the financial resources required are small which measured against the resulting improvement of education of Millions." The statement makes a bold pronouncement of making education an instrument for social and economic transformation of the nation.

\subsection{Concept of Emotional Intelligence}

Emotional intelligence is a psychological construct that has received the attention of many psychologists in recent time. Salovey and Mayer (1990) defines emotional intelligence as the ability to monitor one's own and others' emotions, to discriminate among them and to use the information to guide one's thinking and actions. Mayer and Salovey (1997, p. 401) refined their definition of emotional intelligence as "the ability to perceive accurately, appraise, and express emotion; the ability to access and/or generate feelings when they facilitate thought; the ability to understand emotion and emotional knowledge; and the ability to regulate emotions to promote emotional and intellectual growth". This concept emphasizes the importance of self-awareness and the ability to re-evaluate and balance a person's intellect and emotion within a typical daily life. Emotionally intelligent individuals use their emotions to engage in intelligent thought and also possess the ability to think intelligently about their emotions (Mayer \&Salovey, 1997; Mayer, Salovey, \& Caruso, 2000). Emotional intelligence plays a great role in shaping 
individuals. Goleman (1999) explained that emotional intelligence creates passion, confidence, friendliness, motivation, pride and energy in individuals. The ability to transmit these same emotions to others offers emotionally intelligent people advantages over others in interpersonal and organizational contexts. Emotional intelligence focuses more on emotional problem solving, rather than on the social, political or verbal aspects inherent in the social intelligence construct (Mayer et al, 2000). Definitions or models of emotional intelligence tend to be either ability based or a mixture of abilities and personality traits (Mayer et. al; 2000). The ability based model refers to emotional intelligence as a type of intelligence reflecting the ability to process emotional information (Mayer \& Salovery, 1997). In contrast, the mixed emotional intelligence model incorporates both ability factors and personality traits (Mayer, et al., 2000). Emotional intelligence is an ability that involves the interchange of emotions and intelligence (Mayer, et. al., 2000). People that are emotionally intelligent possess a clear understanding of their feelings, and can restore their moods more quickly than those individuals with low levels of emotional intelligence (Ciarrochi, Chan \& Caputi, 2000).

Emotional Intelligence is very much important to a teacher. It again depends on the emotional health of a teacher. According to Goleman, emotional health of a teacher depends on the following components - i) self-management, ii) Emotional selfawareness, iii) Managing one‘s own decisions, self-motivation, developing empathy iv) personal and work level. EI of a teacher helps to establish social relationships and managing emotions in others. A teacher with high EI communicates with constructive goal in mind and controls his or her emotions carefully rather than just reacting to a situation solely based on impulse generated by an emotion-generating event. Thus, EI is important for teachers in many distinct ways (Goleman, 2005).

\section{OBJECTIVES OF THE STUDY}

\subsection{Major Objectives of This Study Were}

- To assess the level of Emotional Intelligence among the secondary school teachers of Assam.

- To find out the difference between male and female secondary school teachers of Assam in their level of Emotional Intelligence.

- To find out the difference between rural and urban secondary school teachers of Assam in their level of Emotional Intelligence.

\subsection{Hypotheses of the Study}

\section{The Major Hypotheses of the Study Were}

- There is no significant difference between the male and female secondary school teachers of Assam in relation to their Professional ethics.

- There is no significant difference between the rural and urban secondary school teachers of Assam in relation to their Professional ethics.

\section{METHODOLOGY}

In this present study the investigators applied Descriptive Cum Survey of Educational Research in order to assess the emotional intelligence of secondary school teachers of Assam.

\subsection{Population of the Study}


The target population of the present study consisted of rural and urban secondary school teachers of Assam.

\subsection{Sample of the Study}

In this study the investigators used the Stratified Random sampling procedure for collection of data which was consisted of 600 secondary school teachers of Assam.

\subsection{Tools Used in the Study}

In order to assess emotional intelligence of secondary school teachers of Assam the investigators used a self- developed emotional intelligence scale prepared by him.

\subsection{Statistical Techniques Used}

The investigators used inferential statistics as ' $t$ ' test in order to analyze and interpret the result for the purpose of the study.

\section{MAJOR FINDINGS OF THE STUDY}

\subsection{Variable Wise Estimation on Emotional Intelligence of Secondary School Teachers of Assam}

- Objective 1: To assess the level of Emotional Intelligence among the secondary school teachers of Assam.

Table 1: Showing Emotional Intelligence of Secondary School Teachers of Assam

\begin{tabular}{|c|c|c|c|c|c|c|}
\hline \multirow{2}{*}{ Category } & \multicolumn{2}{|c|}{ High (Below Mean + SD) } & $\begin{array}{c}\text { Moderate (Between Mean } \\
\text { - DS to Mean + SD }\end{array}$ & \multicolumn{2}{c|}{ Low (Above Mean + SD) } \\
\cline { 2 - 8 } & No. of Ind. & $\%$ & No. of Ind. & $\%$ & No. of Ind. & $\%$ \\
\hline Emotional Intelligence & 102 & $17 \%$ & 384 & $64 \%$ & 114 & $19 \%$ \\
\hline
\end{tabular}

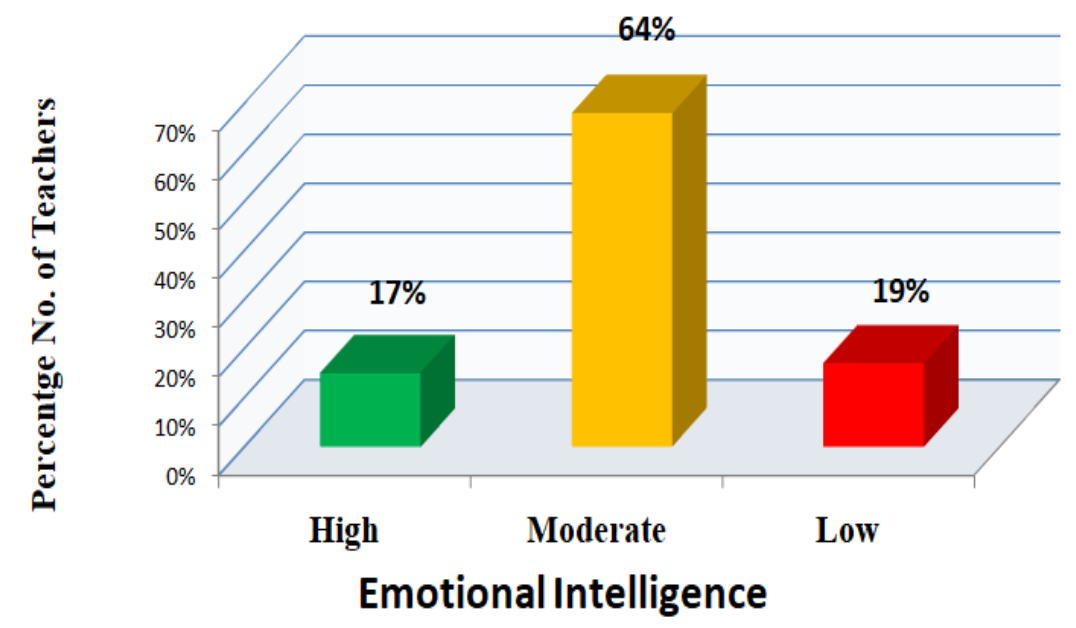

Figure 1: Showing the Graphical Representation of Emotional Intelligence of Secondary School Teachers of Assam.

4.2. Interpretation: An examination in to the Table 1 and Figure 1 depicts that majority of the teachers' Emotional Intelligence scores lies in between the average range. The study depicts that, the Emotional Intelligence of the secondary School teachers of Assam it indicates that majority of the secondary school teachers i.e. $64 \%$ showed high Emotional Intelligence. Whereas only $17 \%$ teachers showed high Emotional Intelligence and $19 \%$ teachers showed low Emotional Intelligence. Form the study it can be concluded that, majority of the secondary school teachers of Assam have moderate Emotional Intelligence. The study also indicates that the government should take proper steps to increase the emotional intelligence level from moderate to high.

- Objective 2: To find out the difference between male and female secondary school teachers of Assam in their level 
of Emotional Intelligence.

- Hypothesis 1: There is no significant difference between the male and female secondary school teachers of Assam in relation to their Professional ethics.

Table 2: Summary of Mean Scores, SD Values, $S E_{D}$ and' $t$ ' Values of Male and Female Secondary School Teachers of Assam in Relation to Their Emotional Intelligence

\begin{tabular}{|l|c|c|c|c|c|c|c|}
\hline \multicolumn{1}{|c|}{ Group } & $\mathbf{N}$ & Mean & SD & $\boldsymbol{S E}_{\boldsymbol{D}}$ & $\begin{array}{c}\text { Computed } \\
\text { 't' value }\end{array}$ & $\begin{array}{c}\text { Criterion 't' } \\
\text { Value }\end{array}$ & Remark \\
\hline Male Teachers & 378 & 794.95 & 84.21 & 7.27 & 0.77 & $\begin{array}{c}1.96 \text { At } 0.05 \text { level } \\
\text { of significance }\end{array}$ & $\begin{array}{c}\text { Not Significant } \\
\mathrm{p}<1.96\end{array}$ \\
\hline Female Teachers & 222 & 789.35 & 86.94 & & & \\
\hline
\end{tabular}

4.3. Interpretation: An examination into the table no. 2 reveals that the computed ' $t$ ' value $(0.77)$ is less than $(<)$ the criterion ' $t$ ' value (1.96) at 0.05 level of significance for df598. As the computed ' $t$ ' value (0.77) is not significant at 0.05 level, therefore the formulated hypothesis (Ho-11) "There is no significant difference between the male and female secondary school teachers of Assam in relation to their emotional Intelligence" gets accepted. From the findings, it is clearly interpreted that, there is no significant difference between the male and female secondary school teachers of Assam in relation to their emotional Intelligence. It indicates that male and female secondary school teachers of Assam had shown equal their emotional Intelligence. By looking at the mean scores of both the male and female secondary school teachers of Assam, it reveals that, the mean score of male secondary school teachers of Assam i.e. (794.95) is slightly higher than the mean score of female secondary school teachers of Assam i.e. (789.35) (shown in the Figure 2). So far the mean scores are concerned; it brings to the light that the male secondary school teachers of Assam to some extent are having better emotional Intelligence in comparison to female secondary school teachers of Assam. This difference may exist because of sampling errors, errors at the time of data collection, or errors in the interpretation of the data. There is no significant difference found among the male and female secondary school teachers of Assam in relation to their emotional intelligence that may be because of same educational environment, same training provided to the teachers.

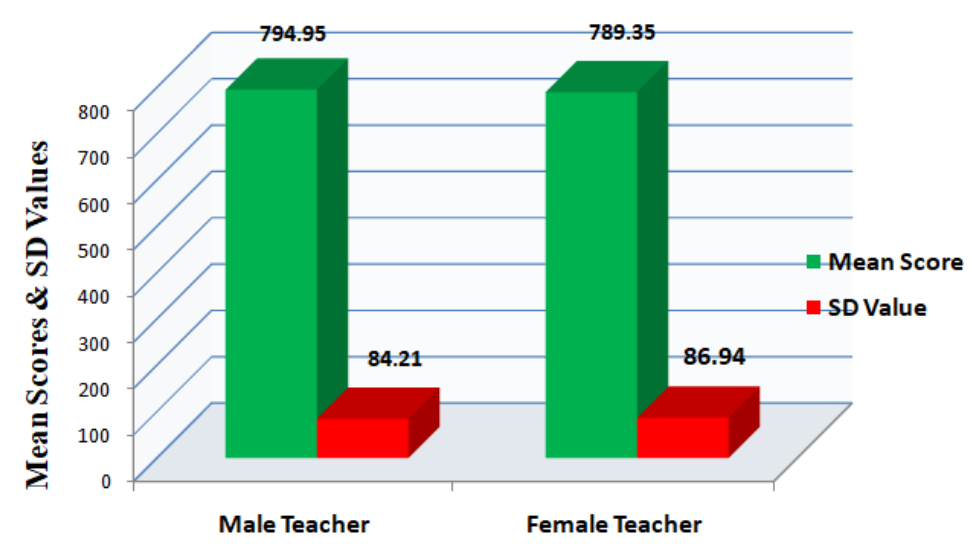

Figure 2: Showing the Mean Scores and SD Values of Male and Female Secondary School Teachers of Assam in Relation to Their Emotional Intelligence.

- Objective 3: To find out the difference between rural and urban secondary school teachers of Assam in their level of Emotional Intelligence.

- Hypothesis 2: There is no significant difference between the rural and urban secondary school teachers of Assam in relation to their Professional ethics. 
Table 3: Summary of Mean Scores, SD Values, $S E_{D}$ and't' Values of Rural and Urban Secondary School Teachers of Assam in Relation to Their Emotional Intelligence

\begin{tabular}{|c|c|c|c|c|c|c|c|}
\hline Group & $\mathbf{N}$ & Mean & SD & $S E_{D}$ & $\begin{array}{l}\text { Computed ' } t \text { ' } \\
\text { value }\end{array}$ & $\begin{array}{c}\text { Criterion ' } t \text { ' } \\
\text { Value }\end{array}$ & Remark \\
\hline Rural Teachers & 300 & 794.06 & 76.17 & \multirow{2}{*}{6.96} & \multirow{2}{*}{0.34} & \multirow{2}{*}{$\begin{array}{l}1.96 \text { At } 0.05 \text { level } \\
\text { of significance }\end{array}$} & \multirow{2}{*}{$\begin{array}{c}\text { Not significant } \\
p<1.96\end{array}$} \\
\hline Urban Teachers & 300 & 791.70 & 93.48 & & & & \\
\hline
\end{tabular}

4.4. Interpretation: The above table no. 3 depicts that the computed ' $t$ ' value $(0.34)$ is smaller than $(>)$ the criterion ' $t$ ' value (1.96) at 0.05 level of significance for df598. As the computed ' $t$ ' value 0.95 is not significant at 0.05 level, henceforth the formulated hypothesis (Ho-12) "There is no significant difference between the Rural and Urban secondary school teachers of Assam in relation to their Emotional Intelligence.' gets accepted. From this, it is clearly understood that, truly there is no significant difference between the rural and urban secondary school teachers of Assam in relation to their Emotional Intelligence. It reveals that rural and urban secondary school teachers of Assam had equal Emotional Intelligence. But, by looking at the Mean scores of both the rural and urban secondary school teachers of Assam, which seems that, the mean score of rural secondary school teachers of Assam i.e. 794.06 is slightly higher than the mean score of urban secondary school teachers of Assam i.e. 791.70 (shown in the diagram no- 3). So far the mean scores are concerned; it signifies that the rural secondary school teachers of Assam are having better emotion intelligence in comparison to the urban-based Teachers. This difference may because of the chance factors or errors in measurement. The result brings to the light that the rural and urban secondary school teachers of Assam have equal Professional Ethics that may because of same educational environment prevailed for rural and urban based secondary school teachers of Assam.

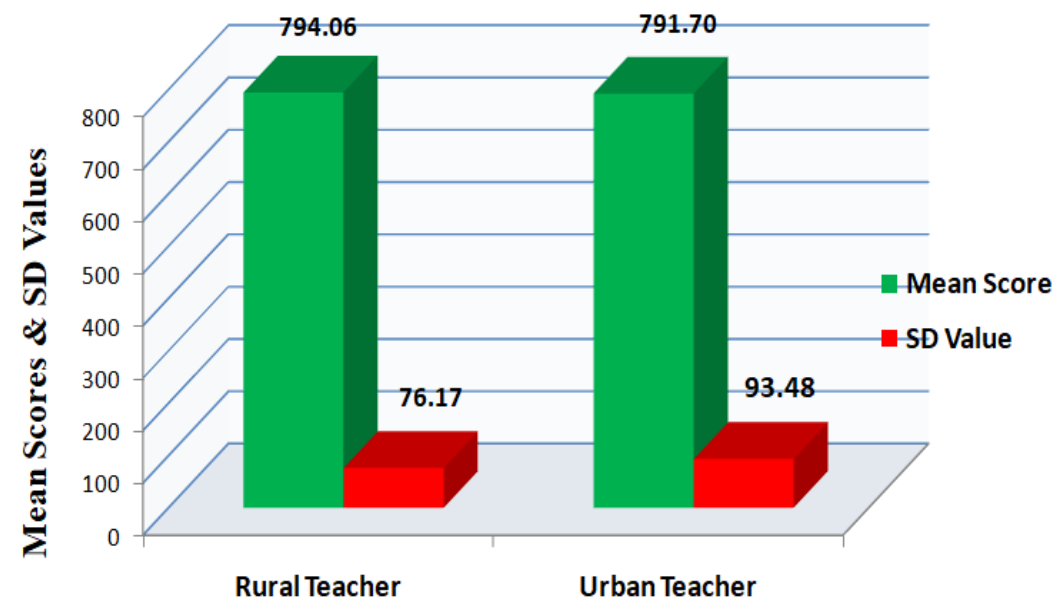

Diagram 3: Showing the Mean Scores and SD Values of Rural and Urban Secondary School Teachers of Assam in Relation to Their Emotional Intelligence.

\section{DISCUSSIONS OF THE RESULTS}

From the above study relating to professional ethics of the secondary school teachers of Assam it was found that majority of the secondary school teachers i.e. $64 \%$ showed moderate Emotional Intelligence. Whereas only $17 \%$ teachers showed high Emotional Intelligence and $19 \%$ teachers showed low Emotional Intelligence. From these findings it is to be interpreted that very few percent teachers of secondary schools of Assam were found having high Emotional Intelligence. Majority of the Secondary school teachers were having moderate professional ethic Emotional Intelligence. The findings of this study also discover that there were no significant difference found in the emotional intelligence among the secondary school teachers of Assam in relation to gender \& Location variables. From this study it was found that the male-female\& rural-urban, 
government had same emotional intelligence. Same emotional intelligence was found among the secondary school teachers of Assam irrespective of gender\& Location variables. It may be because of same environment, Educational plans and policies of the government, same perception and attitude towards teaching profession etc

\section{CONCLUSIONS}

Emotional intelligence is the ability to understand your own emotions and those of people around you. The concept of emotional intelligence means you must have a self-awareness that enables you to recognize feelings and manage our emotions. Emotional Intelligence is very much important to a teacher. It again depends on the emotional health of a teacher. The emotional connection between the teacher and the student is important as it stays forever. Although in a short period burdened with syllabi, a teacher has her limitations to interact with children at an emotional level. However, with little effort and sensitivity towards students' emotional needs, the teacher can develop children of tomorrow with a positive outlook towards life.

\section{REFERENCES}

1. Aggarwal Y.P (2000), Statistical methods, New Delhi: Sterling Publishers Pvt. Ltd.

2. Aggarwal, J.C. (2009), Education for Environment, values and human rights, New Delhi: Shipra Publications.

3. Annaraja, P. and Thiagarajan, A. Poonarbala (1993), "The Effect of Psychological factors on the academic achievement of the scheduled tribe adolescents", Journal of Indian Education, Vol-XVII (6), New Delhi.

4. Aurobindo, (1947), The Doctrine of Passive Resistance, Pondichery: Sri Aurobindo Ashram.

5. Barua, N. (2000). A Study of Job Satisfaction among the Primary School Teachers of Nazira Sub-division.M.Ed. Dissertation, Education Department, Dibrugarh University.

6. Best. J.W. and Kahn, J.V. (2001), Research in Education, New Delhi: Prendicle Hall of India.

7. Buch, M.B. (Ed.) (1991), Fourth Survey of Research in Education, Vol-I and Vol-II, New Delhi: NCERT.

8. Buch, M.B. (Ed.) (1995), Fifth Survey of Research in Education, Vol-I and Vol-II, New Delhi: NCERT.

9. Choudhury, M.R. (1997-98). A Study on Classroom Management and School Climate in Primary Schools of Barpeta Block under Barpeta district-A Comparative Study on the Role of Trained and Untrained Teachers. M.Ed. Dissertation, Gauhati University.

10. DEVI, BINITA, and P. CHAKRABORTY. "COMPUTER EDUCATION BY PRIVATE COMPUTER INSTITUTES: CAPITAL CITY AND RURAL DISTRICT: AN ANALYSIS AND COMPARATIVE STUDY."International Journal of Educational Science And Research (IJESR) 3. 2, Jun 2013, 8588.

11. Garret. H. E. (1981), Statistics in Psychology and Education Bombay: David Makey Company.

12. Gay. L. R. (2000), Educational research-Competencies for analysis and application, New York: The MacMillan Company.

13. Gronlund, N.E. and Linn, R.L. (2000), Measurement and Assessment in Teaching, New York: MacMillan Publishing Company.

14. Kerlinger, F.A. (1973), Foundations of Behavioral Research, Delhi: Surjeet Publications.

15. Khandu, S. and Pradhan S.K. (2010), Higher Education in the Era of Globalization, New Delhi: GESD, Vol-3(4), Academic Excellence.

16. Koul. L. (1997), Methodology of Educational Research, New Delhi: Vikas Publishing House.

17. Lego. L. (2006), Ancient and Medieval History of Arunachal Pradesh, Itanagar: Pothighar. 
18. MANNA, RAKESH, and JAYANTA METE."Secondary teacher education system in India with special reference to West Bengal." International Journal of Humanities and Social Sciences 5.3 (2016): 97111.

19. Nayak. B.K. (2001) Textbook on Foundations of Education, Cuttack: Kitab Mahal.

20. NCERT. (Ed.) (2000), Sixth Survey of Educational Research, Vol-I and Vol-II, New Delhi: NCERT.

21. Pradhan, S.K. (2011), Equity, Excellence and Global Competitiveness- A Theoritical Framework for Higher Educational Institutions, New Delhi: University News, Vol-49(8), and AIU.

22. Saikia, P. (2010), Environmental awareness and attitude towards environmental education among the college teachers and students in Arunachal Pradesh and Assam- A comparative study, Ph.D. Edu., RGU, Itanagar.

23. Sarma, H.K.; Choudhury, S.K. and Sarmah, J.K. (2003).Efficacies of Teacher Educators in Providing Quality Training to Elementary Teachers - A Case Study. SCERT, Assam.

24. SARMA, MOYURI. "ENVIRONMENTAL EDUCATION FOR SUSTAINABLE DEVELOPMENT: A STUDY CONDUCTED IN THE SCHOOLS OF GREATER GUWAHATI, ASSAM."International Journal of Civil, Structural, Environmental and Infrastructure Engineering Research and Development (IJCSEIERD) 7,.4, Aug 2017, 9-14.

25. SINHA, ARBIND. "ICT AND EDUCATION: A STUDY OF CHANGING DYNAMICS IN INDIA."International Journal of Educational Science and Research (IJESR) 3. 4, Oct 2013, 3346. 

